\title{
Nuclear translocation of PKC- $\alpha$ is associated with cell cycle arrest and erythroid differentiation in myelodysplastic syndromes (MDSs)
}

\begin{abstract}
Alessandro Poli, ${ }^{,},+, 1$ Stefano Ratti, ${ }^{*, 1}$ Carlo Finelli, ${ }^{\ddagger}$ Sara Mongiorgi, ${ }^{*}$ Cristina Clissa, ${ }^{\ddagger, \S}$ Annalisa Lonetti, ${ }^{*, \uparrow}$ Alessandra Cappellini," Alessia Catozzi,* Marilena Barraco, ${ }^{*}$ Pann-Ghill Suh,, Lucia Manzoli,* James A. McCubrey, ${ }^{* *}$ Lucio Cocco, ${ }^{*, 2}$ and Matilde Y. Follo, ${ }^{*, 3}$

${ }^{*}$ Cellular Signalling Laboratory, Institute of Human Anatomy, Dipartimento di Scienze Biomediche e NeuroMotorie, ${ }^{\ddagger}$ L. and E. Seràgnoli Institute of Hematology, and "Lalla Seràgnoli Department of Pediatrics, Policlinico Sant'Orsola-Malpighi Hospital, University of Bologna, Bologna, Italy; ${ }^{\dagger}$ Istituto Nazionale Genetica Molecolare, Fondazione Romeo e Enrica Invernizzi, Milan, Italy; ${ }^{\S}$ Hematology and Stem Cell Transplant Center, San Salvatore Hospital, Pesaro, Italy; "Department of Human Social Sciences and Health, University of Cassino, Cassino, Italy; ${ }^{\#}$ School of Life Sciences, Ulsan National Institute of Science and Technology, Ulsan, South Korea; and **Department of Microbiology and Immunology, Brody School of Medicine, East Carolina University, Greenville, North Carolina, USA
\end{abstract}

ABSTRACT: PI-PLC $\beta 1$ is involved in cell proliferation, differentiation, and myelodysplastic syndrome (MDS) pathogenesis. Moreover, the increased activity of PI-PLC $\beta 1$ reduces the expression of PKC- $\alpha$, which, in turn, delays the cell proliferation and is linked to erythropoiesis. Lenalidomide is currently used in low-risk patients with MDS and del(5q), where it can suppress the del(5q) clone and restore normal erythropoiesis. In this study, we analyzed the effect of lenalidomide on 16 patients with low-risk del(5q) MDS, as well as del(5q) and non-del(5q) hematopoietic cell lines, mainly focusing on erythropoiesis, cell cycle, and PI-PLC $\beta 1 /$ PKC- $\alpha$ signaling. Overall, 11 patients were evaluated clinically, and $10(90 \%)$ had favorable responses; the remaining case had a stable disease. At a molecular level, both responder patients and del(5q) cells showed a specific induction of erythropoiesis, with a reduced $\gamma / \beta$-globin ratio, an increase in glycophorin A, and a nuclear translocation of PKC- $\alpha$. Moreover, lenalidomide could induce a selective $\mathrm{G}_{0} / \mathrm{G}_{1}$ arrest of the cell cycle in del $(5 q)$ cells, slowing down the rate proliferation in those cells. Altogether, our results could not only better explain the role of PI-PLC 1 1/PKC- $\alpha$ signaling in erythropoiesis but also lead to a better comprehension of the lenalidomide effect on $\operatorname{del}(5 q)$ MDS and pave the way to innovative, targeted therapies.-Poli, A., Ratti, S., Finelli, C., Mongiorgi, S., Clissa, C., Lonetti, A., Cappellini, A., Catozzi, A., Barraco, M., Suh, P.-G., Manzoli, L., McCubrey, J. A., Cocco, L., Follo, M. Y. Nuclear translocation of PKC- $\alpha$ is associated with cell cycle arrest and erythroid differentiation in myelodysplastic syndromes (MDSs). FASEB J. 32, 681-692 (2018). www.fasebj.org

KEY WORDS: nucleus $\cdot$ erythropoiesis $\cdot$ lenalidomide $\cdot$ chromosome $5 q$ deletion

Lenalidomide is an immunomodulating drug that is currently being used in patients diagnosed with myelodysplastic syndromes (MDSs) who also bear a deletion in the

ABbreviAtions: $\mathrm{CI}$, confidence interval; $\mathrm{CR}$, complete remission; $\mathrm{EPO}$, erythropoietin; GPA, glycophorin A; HI-E, hematologic improvement along the erythroid lineage; HRP, horseradish peroxidase; IWG, International Working Group; MDS, myelodysplastic syndrome; MNC, mononuclear cell; PP2CA, protein phosphatase 2A catalytic subunit- $\alpha$; R-IPSS, revised international prognostic scoring system; RPMI, Roswell Park Memorial Institute; WHO, World Health Organization

${ }^{1}$ These authors contributed equally to this work.

${ }^{2}$ Correspondence: Cellular Signalling Laboratory, Institute of Human Anatomy, Dipartimento di Scienze Biomediche e NeuroMotorie, University of Bologna, via Irnerio 48, I-40126 Bologna, Italy. E-mail: lucio. cocco@unibo.it

${ }^{3}$ Correspondence: Cellular Signalling Laboratory, Institute of Human Anatomy, Dipartimento di Scienze Biomediche e NeuroMotorie, University of Bologna, via Irnerio 48, 40126 Bologna, Italy. E-mail: matilde. follo@unibo.it

doi: 10.1096/fj.201700690R long arm of chromosome 5 [del(5q)] (1). Indeed, in these cases of low-risk MDS, lenalidomide may suppress the del (5q) clone and restore normal erythropoiesis $(2,3)$. Moreover, in lenalidomide-sensitive $\operatorname{del}(5 \mathrm{q})$ cell lines, Akt phosphorylation is inhibited and cell cycle arrest is detected (4). Interestingly, Akt signaling is specifically activated in high-risk MDS, where it induces cell proliferation, and in low-risk MDS, where it is involved in erythropoiesis (5-7). In addition, during both erythropoiesis and erythropoietin-induced erythroid differentiation of CD $34^{+}$ progenitor cells, phosphoinositides phosphorylated by PI3K can act as secondary messengers to directly activate Akt and certain isoforms of PKC, particularly PKC- $\alpha$ (8).

PKC- $\alpha$ is a downstream target of PI-PLC $\beta 1$ (9), a key enzyme of the PI metabolism (10-12). Indeed, the PI cycle usually includes PLC $(13,14)$, a class of enzymes able to hydrolyze phosphatidylinositol 4,5-biphosphate to produce inositol 1,4,5-trisphosphate and diacylglycerol, 
whose nuclear localization is involved in the activation of PKCs (15). Therefore, the PI cycle has an essential role in the regulation of cell proliferation and differentiation (16-18) but is also implicated in immunomodulation processes (19).

Interestingly, PI-PLC $\beta 1$ is involved in the MDS progression to acute myeloid leukemia and in the response to epigenetic drugs (20-26). Moreover, the nuclear splicing variant of PI-PLC $\beta 1$ is a negative regulator of erythroid differentiation and is reduced in both erythropoietinresponder, low-risk patients with MDS and in normal hematopoietic progenitors induced to erythroid differentiation $(7,27)$. Furthermore, increased PI-PLC $\beta 1$ activity reduces PKC- $\alpha$ levels, which, in turn, can induce a delay in cell proliferation (28). Notably, the above-mentioned decrease in PKC- $\alpha$ has been found in total lysates of the human K562 erythroleukemia cell line, but the behavior of PKC- $\alpha$ could change in nuclear and cytoplasmic fractions. Indeed, the cellular localization of the PI metabolism is extremely important because its enzymes may have different regulations and functions according to their localization (29-32).

Stemming from these data, here we investigated the molecular effect of lenalidomide on erythroid differentiation in low-risk MDS cells and on the PI-PLC $\beta 1 /$ PKC- $\alpha$ signaling pathway. Because we used mononuclear cells (MNCs) from patients with $\operatorname{del}(5 q)$ and MDS, where del (5q) and non-del(5q) cells are both present, we also tested
Namalwa CSN.70 and U937 hematopoietic cell lines, which have a del(5q) and a non-del(5q) karyotype, respectively. We particularly focused on the topographic localization of PI-PLC $\beta 1$ and PKC- $\alpha$ during lenalidomideinduced erythroid differentiation, because the presence of these enzymes in a particular cellular district could explain the different activations of signaling pathways during lenalidomide therapy, thus leading to a comprehension of a new molecular mechanism for lenalidomide therapy and the identification of possible molecular markers that could be used to develop innovative, targeted therapies for patients with del(5q) and MDS.

\section{MATERIALS AND METHODS}

\section{Patient characteristics}

Peripheral blood MNCs from 16 patients with del(5q) MDS treated with lenalidomide alone, who had given informed consent according to the Declaration of Helsinki, were examined (Table 1). All samples came from the L. and E. Seràgnoli Institute of Hematology, Policlinico Sant'Orsola-Malpighi Hospital. An MDS diagnosis was defined according to the World Health Organization (WHO) classification (33), and, according to the revised international prognostic scoring system (R-IPSS) (34), patients were divided into 2 subgroups by risk: intermediate risk $(n=6)$ and low-risk $(n=10)$. However, throughout the text, all patients with MDS are defined as low-risk MDS.

TABLE 1. Patients' characteristics

\begin{tabular}{|c|c|c|c|c|c|c|c|c|c|c|}
\hline \multirow{2}{*}{$\begin{array}{l}\text { Case } \\
\text { No. }\end{array}$} & \multicolumn{2}{|c|}{ Diagnosis } & \multirow[b]{2}{*}{ Screening } & \multirow[b]{2}{*}{ Age } & \multirow[b]{2}{*}{ Sex } & \multirow[b]{2}{*}{ Karyotype } & \multirow{2}{*}{$\begin{array}{l}\text { Cycles } \\
(n)\end{array}$} & \multirow{2}{*}{$\begin{array}{l}\text { Clinical } \\
\text { outcome }\end{array}$} & \multirow{2}{*}{$\begin{array}{c}\text { Survival } \\
(\mathrm{mo})\end{array}$} & \multirow{2}{*}{$\begin{array}{c}\text { Cause of } \\
\text { death }\end{array}$} \\
\hline & WHO & R-IPSS & & & & & & & & \\
\hline 1 & $5 q^{-}$ & Low & $\begin{array}{l}\text { October } \\
2010\end{array}$ & 80 & $\mathrm{~F}$ & $\operatorname{del}(5 q)$ & 56 & HI-E & 70 & \\
\hline $2^{a}$ & $5 q^{-}$ & Low & April 2011 & 90 & M & $\operatorname{del}(5 q)$ & 1 & $\mathrm{NE}$ & 1 & Stroke \\
\hline 3 & $\mathrm{RA}$ & Low & April 2011 & 86 & M & $\begin{array}{c}\operatorname{del}(5 q) ; \operatorname{del}(20) \\
(q 11 ; q 13)\end{array}$ & 1 & $\mathrm{NE}$ & 6 & \\
\hline $4^{a}$ & $5 q-$ & Low & $\begin{array}{l}\text { September } \\
2012\end{array}$ & 83 & $\mathrm{~F}$ & $\operatorname{del}(5 q)$ & 5 & CR & 14 & Pneumonia \\
\hline $5^{a}$ & $5 q-$ & Low & $\begin{array}{c}\text { February } \\
2012\end{array}$ & 72 & $\mathrm{~F}$ & $\operatorname{del}(5 q)$ & 29 & CR & 32 & Sepsis \\
\hline 6 & $5 q^{-}$ & Low & $\begin{array}{c}\text { January } \\
2015\end{array}$ & 80 & $\mathrm{~F}$ & $\operatorname{del}(5 q)$ & 16 & HI-E +cyt.resp. & 20 & \\
\hline 7 & $5 q^{-}$ & Int & $\begin{array}{l}\text { November } \\
2015\end{array}$ & 81 & $\mathrm{~F}$ & $\operatorname{del}(5 q)$ & 6 & SD & 10 & \\
\hline 8 & $5 q^{-}$ & Low & $\begin{array}{c}\text { February } \\
2015\end{array}$ & 74 & M & $\operatorname{del}(5 q)$ & 17 & HI-E +cyt.resp. & 19 & \\
\hline 9 & RA & Int & $\begin{array}{c}\text { January } \\
2011\end{array}$ & 71 & $\mathrm{~F}$ & $\operatorname{del}(5 q) ; \mathrm{t}(2 ; 11)$ & 29 & HI-E & 68 & \\
\hline 10 & $5 q^{-}$ & Low & April 2014 & 72 & $\mathrm{~F}$ & $\operatorname{del}(5 q)$ & 1 & $\mathrm{NE}$ & 29 & \\
\hline 11 & RA & Int & May 2014 & 76 & $\mathrm{~F}$ & $\operatorname{del}(5 q) ; \operatorname{del}(20 q)$ & 2 & $\mathrm{NE}$ & 28 & \\
\hline $12^{a}$ & RAEB -1 & Int & June 2015 & 70 & M & $\operatorname{del}(5 q)(q 22 q 33)$ & 3 & $\mathrm{NE}$ & 7 & Brain tumor \\
\hline 13 & $5 q^{-}$ & Low & $\begin{array}{l}\text { February } \\
2013\end{array}$ & 82 & $\mathrm{~F}$ & $\operatorname{del}(5 q)$ & 40 & CR & 43 & \\
\hline 14 & $5 q^{-}$ & Int & July 2009 & 69 & $\mathrm{~F}$ & $\operatorname{del}(5 q)$ & 24 & CR & 86 & \\
\hline $15^{a}$ & RA & Int & April 2011 & 79 & $\mathrm{~F}$ & $\begin{array}{r}\operatorname{del}(2 \mathrm{p})(\mathrm{p} 21 \mathrm{p} 25) ; \\
\operatorname{del}(5 \mathrm{q})(\mathrm{q} 22 \mathrm{q} 23)\end{array}$ & 14 & CR & 28 & Sepsis \\
\hline 16 & RA & Low & July 2016 & 76 & $\mathrm{~F}$ & $\operatorname{del}(5 q)(q 13 q 33)$ & 5 & HI-E & 5 & \\
\hline
\end{tabular}

$5 q-$, MDS with isolated $\operatorname{del}(5 q)$; F, female; HI-E+cyt. resp, hematologic improvement-erythroid with cytogenetic response; Int, intermediate risk; Low, low risk; M, male; NE, not evaluable; RA, refractory anemia; RAEB-1, refractory anemia with excess of blasts-1; SD, stable disease. ${ }^{a}$ Patient died. 


\section{Patient treatment and evaluation of response}

To begin, 16 patients with del(5q) underwent lenalidomide treatment $(10 \mathrm{mg} / \mathrm{d}, \mathrm{d} 1-21)$, but 2 patients died before the fourth cycle ( 1 from a stroke and 1 from a brain tumor) and another 3 patients did not reach four cycles of therapy for other reasons. Therefore, only 11 patients were evaluated clinically for hematologic response, and had both clinical and molecular analyses performed. We recorded the response to treatment [according to the revised International Working Group (IWG) response criteria (35)], survival (calculated from the start of lenalidomide), and causes of death (Table 1). Data were censored when patients died or were lost during follow-up. Patients who achieved a complete remission (CR), partial remission, or any hematologic improvement (HI), according to the IWG criteria (35), were considered responders, whereas all the other outcomes were defined as nonresponders. The duration of response was assessed in patients who showed a clinical response to treatment.

\section{Isolation of MNCs from peripheral blood samples}

For in vitro experiments, peripheral blood MNCs were isolated by Ficoll-Paque (GE Healthcare, Waukesha, WI, USA) density-gradient centrifugation, according to the manufacturer's instructions. All analyses were performed on samples from patients at baseline, and subsequently, once a month during lenalidomide therapy. MNCs from healthy subjects were also extracted.

\section{Antibodies and reagents}

The following antibodies and reagents were purchased from commercial sources. Mouse mAbs to cyclin D3 (2936), rabbit pAbs to cyclin E (2925), histone 3A (H3A, 9715), horseradish peroxidase (HRP)-conjugated anti-rabbit IgG (707), HRPconjugated anti-mouse IgG (7076), and the Phototope-HRP western blot detection system (7071) were from Cell Signaling Technology (Danvers, MA, USA). Rabbit protein phosphatase 2A (PP2CA; sc-130237), rabbit cyclin D3 (sc-182), mouse PKC- $\alpha$ (sc-8393), and mouse PI-PLC $\beta 1$ (sc-5291) antibodies were from Santa Cruz Biotechnology (Santa Cruz, CA, USA). Mouse $\beta$-tubulin was from Sigma-Aldrich (St. Louis, MO, USA). Phycoerythrin-conjugated mouse $\mathrm{mAb}$ to CD71 or glycophorin A were from Miltenyi Biotec $\mathrm{GmbH}$ (Bergisch Gladbach, Germany). The FITC-conjugated $\mathrm{F}\left(\mathrm{ab}^{\prime}\right)_{2}$ fragment of goat anti-mouse IgG (F2883) and the Cy3-conjugated $\mathrm{F}\left(\mathrm{ab}^{\prime}\right)_{2}$ fragment of goat anti-rabbit IgG (C2306) were from Sigma-Aldrich.

\section{Cell cultures}

Human Namalwa CSN.70 Burkitt lymphoma cells [i.e., del(5q) cells] and U937 histiocytic lymphoma cells [i.e., non-del(5q) cells] were cultured at $37^{\circ} \mathrm{C}$ with $5 \% \mathrm{CO}_{2}$ in Roswell Park Memorial Institute (RPMI-1640 medium (Lonza, Basel, Switzerland), supplemented with $10 \%$ heat-inactivated fetal bovine serum and streptomycin/penicillin at an optimal cell density of $0.3-0.8 \times 10^{6}$ cells $/ \mathrm{ml}$. Cells were treated with $1 \mu \mathrm{M}$ lenalidomide (CDS022536; Sigma-Aldrich) for $10 \mathrm{~d}$ to give cells a concentration comparable to the plasma concentration reached in clinical uses. Samples were taken on d 6, 8, and 10 to monitor the molecular effect of lenalidomide.

\section{Flow cytometric analysis of cell cycle}

Cells were cultivated in RPMI-1640 medium with lenalidomide. The subdiploid DNA content was evaluated using an FC500
Dual Laser Flow Cytometer with the appropriate software (System II; Beckman Coulter, Brea, CA, USA), as reported in Buontempo et al. (36). At least 10,000 events/sample were acquired.

\section{Flow cytometric detection of glycophorin A and CD71 levels}

For detection of glycophorin A (GPA) and CD71 surface antigens, cells were cultivated in RPMI-1640 medium with lenalidomide. The percentage of positive cells was quantified using an FC500 Dual Laser Flow Cytometer with the appropriate software, as reported in Lonetti et al. (37). At least 10,000 events/sample were acquired.
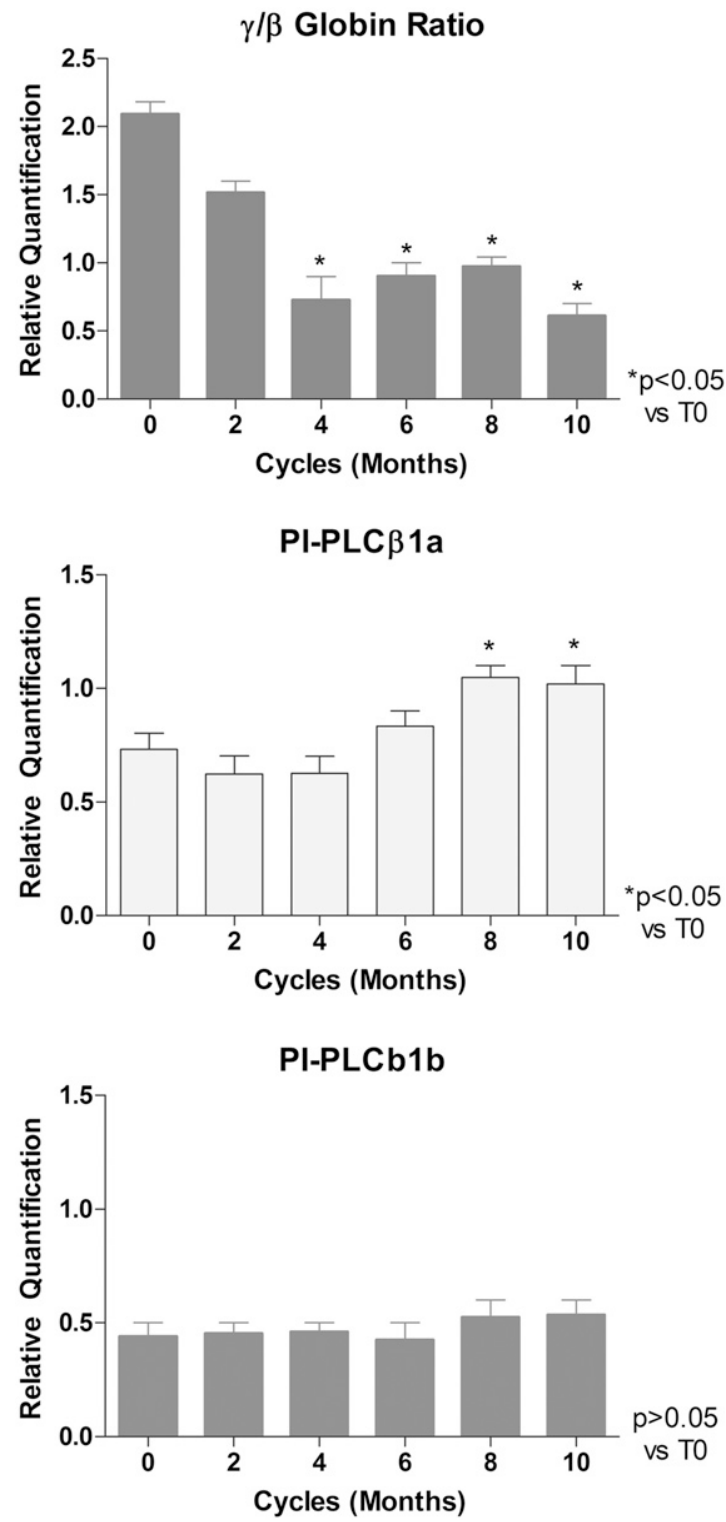

Figure 1. Lenalidomide reduces $\gamma / \beta$ globin ratio and induces PI-PLC $\beta$ la mRNA in patients with MDS who responded to treatment. The $\gamma / \beta$-globin ratio significantly decreased during therapy in those patients. For PI-PLC $\beta 1$ gene expression, the PLC $\beta$ la splicing variant was induced by lenalidomide in the last cycles of treatment, whereas the PI-PLC $\beta 1 \mathrm{~b}$ splicing variant was not affected. $* P<0.05$ vs. time zero $\left(T_{0}\right)$. Data are representative of $\geq 3$ independent experiments. 


\section{Nucleic acids extraction}

Total RNA and total MNCs from patients with MDS and healthy subjects were isolated from cell lines with the RNeasy Mini Kit (Qiagen, Hilden, Germany), according to the manufacturer's protocol, then RNA was retrotranscribed, as described in Follo et al. (38).

\section{Analysis of gene and protein expression}

The gene expression of PI-PLC $\beta 1 \mathrm{a}$, PI-PLC $\beta 1 b, \beta$-globin, and $\gamma$-globin was quantified with a specific TaqMan Real-Time PCR method (Thermo Fisher Scientific, Waltham, MA, USA), as described in Follo et al. (39). A pool of healthy subjects was used as an internal reference, whereas glyceraldehyde 3-phosphate dehydrogenase was used as the housekeeping gene. Because there were few MDS cells, protein expression was examined only by immunocytochemical analyses on MNCs, as previously illustrated (40). For cell lines, we performed a Western blot analysis, and the nuclear/cytoplasmic fractionation was performed as previously reported (41). $\beta$-tubulin was used as a control for equal protein loading in total lysates, whereas the purity of nuclear and cytoplasmic fractions were tested with either $\beta$-tubulin (cytoplasmic marker) or H3A (nuclear marker) antibodies.

\section{Statistical analyses}

All the analyses were performed by using the Prism software (v.4.0; GraphPad Software, La Jolla, CA, USA). Dunnett's test after ANOVA was used to compare continuous values. Tests were considered statistically significant when the value was $P<$ 0.05 .

\section{RESULTS}

\section{Patient outcomes}

Between July 2009 and December 2016, 16 patients with low-risk, del $(5 q)$ MDS were treated with lenalidomide.
A
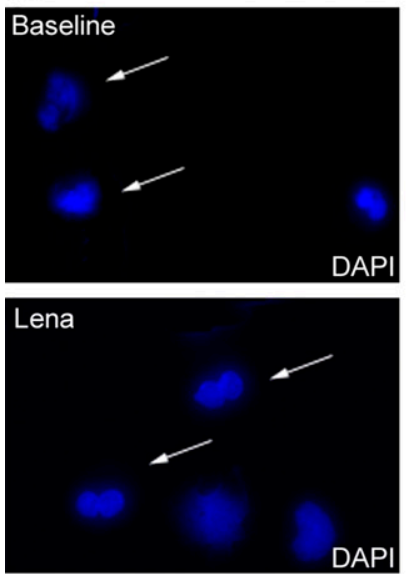

B
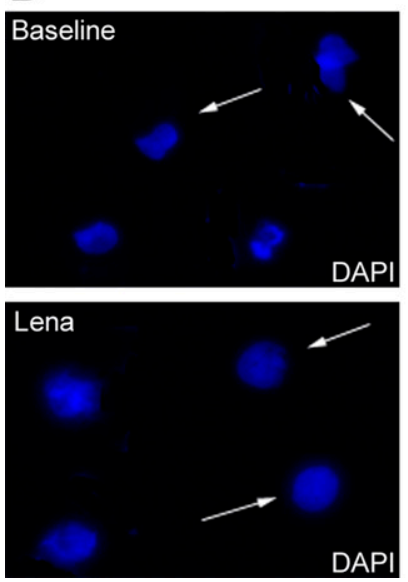
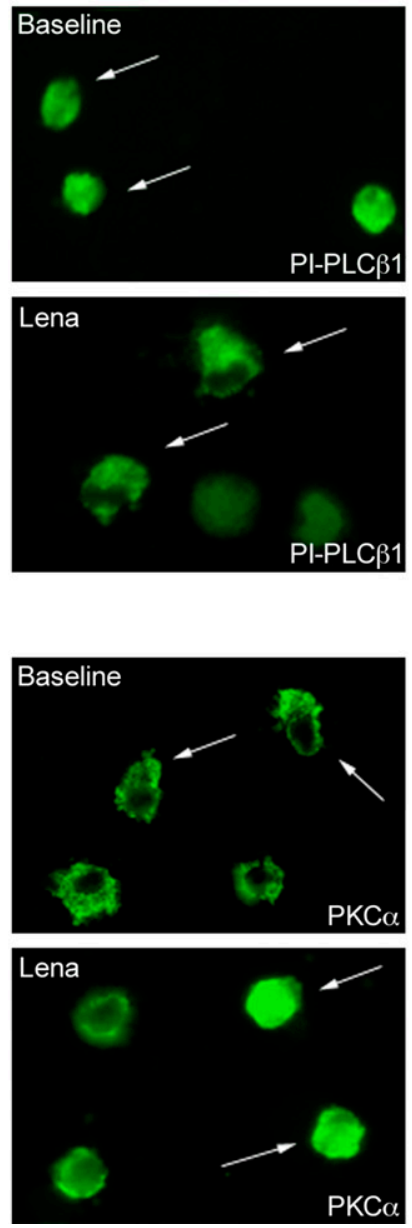
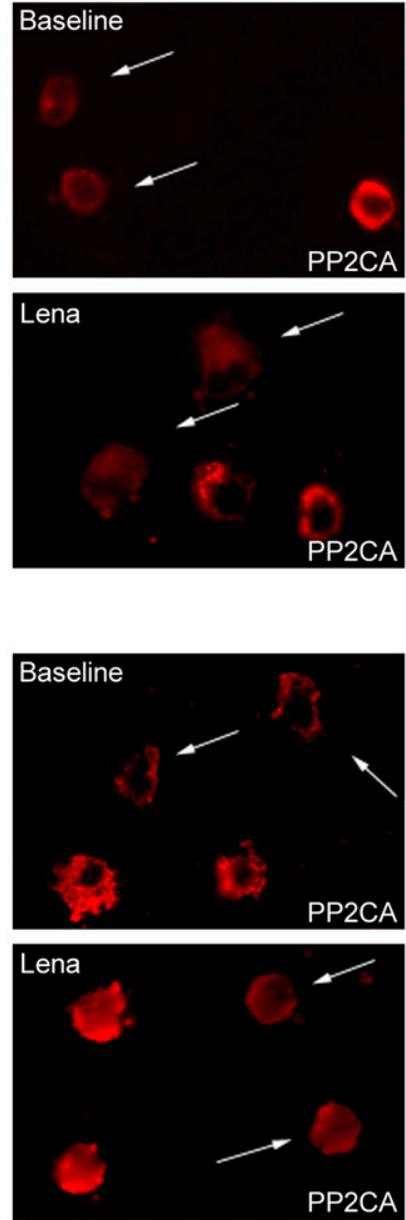
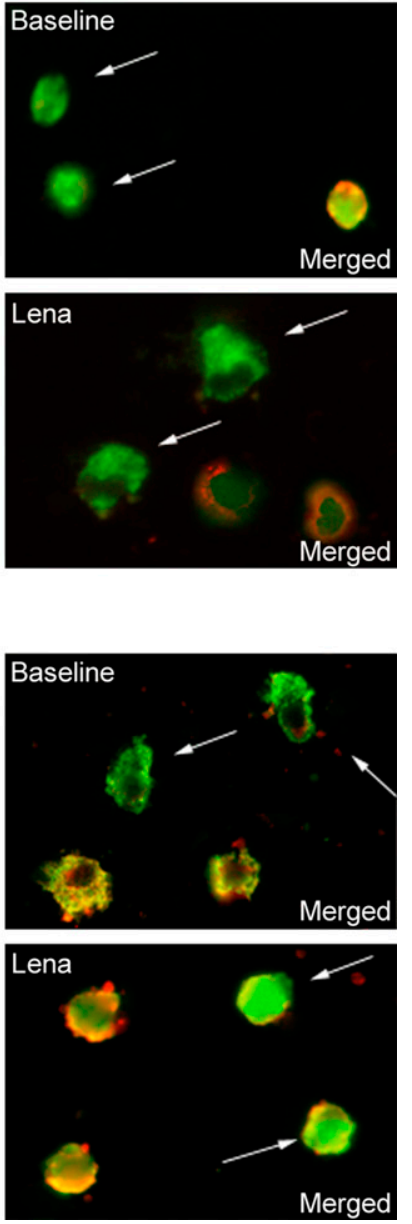

Figure 2. Lenalidomide induces cytoplasmic PI-PLC $\beta 1$ and nuclear PKC- $\alpha$ in patients with MDS who responded to treatment. Representative immunocytochemical analysis of MNCs from those patients treated with lenalidomide. Original magnification, $\times 600$. Nuclei were visualized with DAPI staining (blue signal). A) Levels of PI-PLC $\beta 1$ in MDS at baseline and after lenalidomide (Lena) therapy (green signal). The identification of del(5q) cells was performed with a Cy3-conjugated anti-PP2CA antibody (red signal). The merged image for PI-PLC $\beta 1$ and PP2CA staining indicates colocalization of the 2 antigens (yellow signal). Arrows indicate the $\operatorname{del}(5 q)$ cells. $B$ ) Levels of PKC- $\alpha$ in MDS at baseline and after lenalidomide (Lena) therapy (green signal). The identification of del(5q) cells was performed with a Cy3-conjugated anti-PP2CA antibody (red signal). The merged image for PKC- $\alpha$ and PP2CA staining indicates colocalization of the 2 antigens (yellow signal). Data are representative of $\geq 2$ independent experiments. Arrows indicate the del(5q) cells. 
Median age was $77 \mathrm{yr}$ (range, 69-90 yr), and the median follow-up period was 24 mo (range, 1-86 mo). Eleven patients reached at least four cycles of therapy and were able to be evaluated for response. According to the revised IWG criteria (34), 10 patients $(90 \%)$ showed a favorable response to the treatment (5 patients with CR, 3 with HI-E, and $2 \mathrm{HI}-\mathrm{E}$ and cytogenetic response). The remaining patient had a stable disease (Table 1).

\section{Lenalidomide effect on globin genes and PI-PLCB1 in patients with low-risk MDS}

The ratio between $\gamma$ and $\beta$-globin mRNAs was quantified in patients with low-risk MDS at baseline and during therapy (Fig. 1). A reduction in the $\gamma / \beta$-globin ratio was detected only in responder patients, with a statistically significant difference before and after treatment [Student's $t$ test, $P<0.05$ vs. baseline, 95\% confidence interval (95\% CI), 0.85-1.85]. In addition, the amount of both PI-PLC $\beta 1$ splicing variants was assessed and showed an interesting, specific behavior in responder cases (Fig. 1): PI-PLC $\beta 1$ a increased significantly only in the late cycles of therapy (Student's $t$ test, $P<0.05$ vs. baseline, 95\% CI -0.63 to $+0.05)$, whereas PI-PLC $\beta 1 \mathrm{~b}$ mRNA was not significantly induced by the therapy (Student's $t$ test, $P>0.05$ vs. baseline, $95 \% \mathrm{CI}-0.38$ to +0.19 ).

\section{Lenalidomide effect on PI-PLC $\beta 1$ and PKC- $\alpha$ protein expression in patients with low-risk MDS}

To determine the effect of lenalidomide therapy on the expression of PI-PLC $\beta 1$ and its downstream target PKC- $\alpha$ on $\operatorname{del}(5 q)$ MDS cells, we performed double-immunostaining

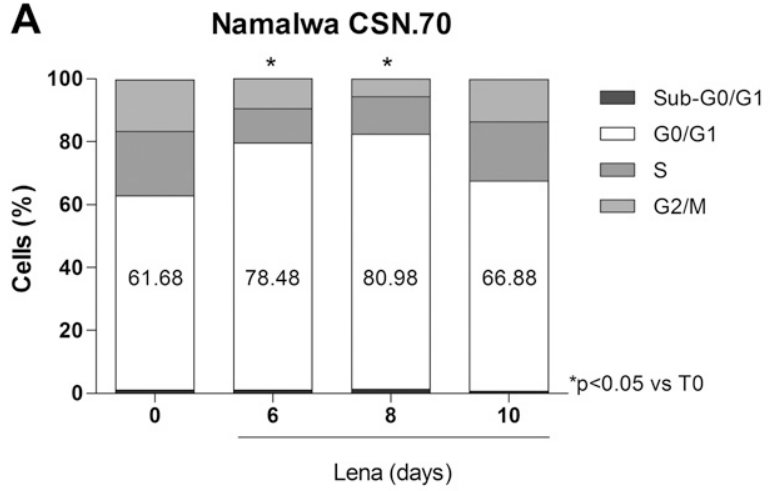

B
NAMALWA CSN.70

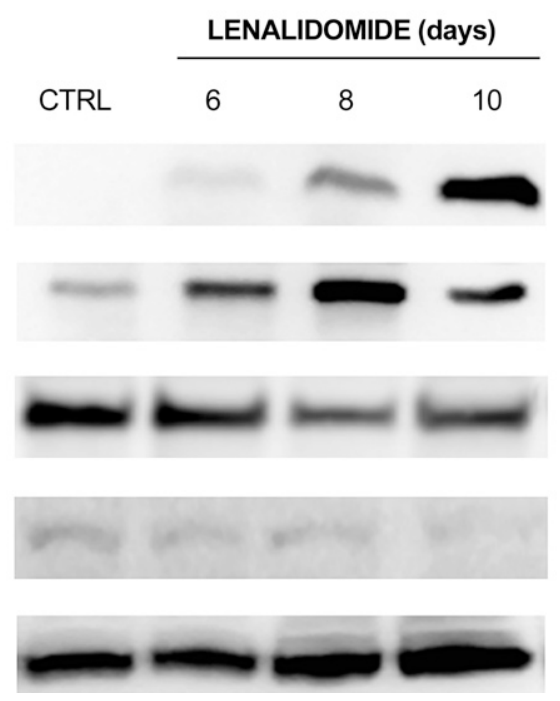

U937

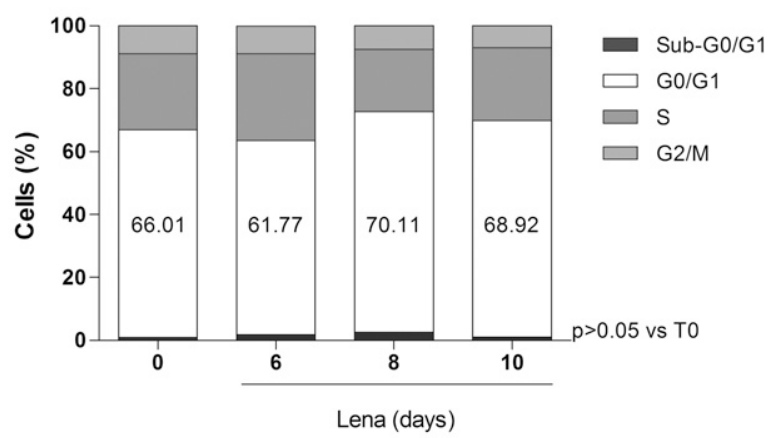

U937

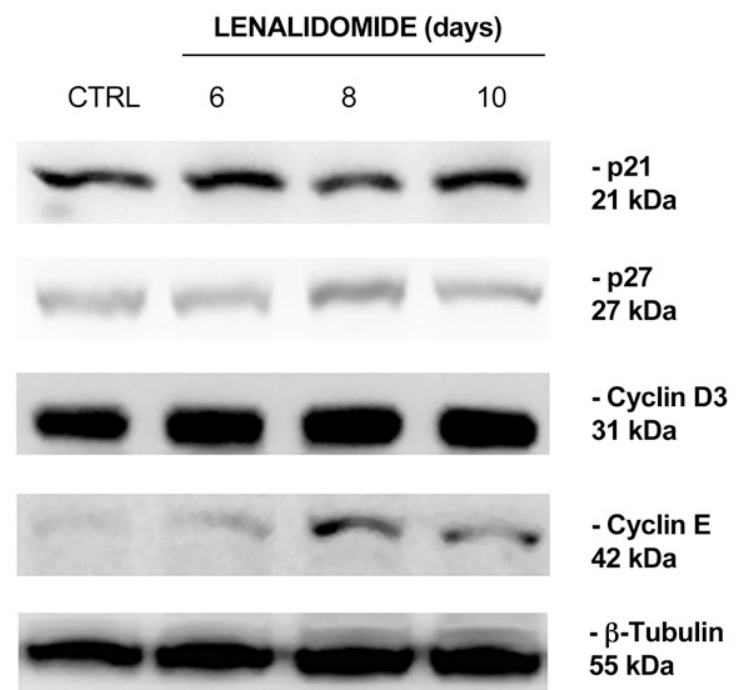

Figure 3. Lenalidomide induces cell cycle arrest in the $\mathrm{G}_{0} / \mathrm{G}_{1}$ phase in Namalwa CSN.70 del(5q) cells. A) Flow cytometric analysis of PI-stained cells treated with $1 \mu \mathrm{M}$ lenalidomide (Lena) for up to $10 \mathrm{~d}$ (as indicated). Histograms report the cell percentage for each phase. ${ }^{*} P<0.05$ vs. $T_{0}$. Lenalidomide significantly increased the $\mathrm{G}_{0} / \mathrm{G}_{1}$ cell fraction only in Namalwa CSN.70 cells $[$ i.e., $\operatorname{del}(5 q)$ cells], with the consequent decrease of the other cell cycle phases. The treatment did not significantly perturb the cell cycle of the U937 cell line [i.e., non-del(5q) cells]. Data are representative of $\geq 3$ independent experiments. $B$ ) Western blotting experiments documented that, in Namalwa CSN.70 cells [i.e., del(5q) cells], lenalidomide induced expression of p27 and p21, along with a slight reduction in cyclin D3 and cyclin E. On the contrary, U937 cells [i.e., non-del(5q) cells] were not significantly affected. Antibody to $\beta$-tubulin served as a loading control. Molecular weights are indicated on the right. Data are representative of $\geq 3$ independent experiments. 
experiments, codetecting the expression of the proteins of interest and PP2CA, which is mapped on chromosome band $5 q$. Figure 2 reports the results obtained from patients with MDS who responded to lenalidomide therapy; as compared with baseline, PI-PLC $\beta 1$ localization seemed to become mainly cytoplasmic, especially in cells not expressing high levels of PP2CA [i.e., del(5q) cells], whereas in the same cells PKC- $\alpha$ localized within the nucleus. In contrast, in cells expressing higher levels of PP2CA [i.e., non-del(5q) cells], PI-PLC $\beta 1$ localization was more nuclear than cytoplasmic, whereas PKC- $\alpha$ was generally detectable in the cytoplasm.

\section{Flow cytometric analysis of the cell cycle in $\operatorname{del}(5 q)$ and non-del(5q) cell lines}

The effect of lenalidomide on the cell cycle was studied by a flow cytometric analysis of PI-stained, hematopoietic, del(5q) and non-del (5q) cell lines. As compared with

A
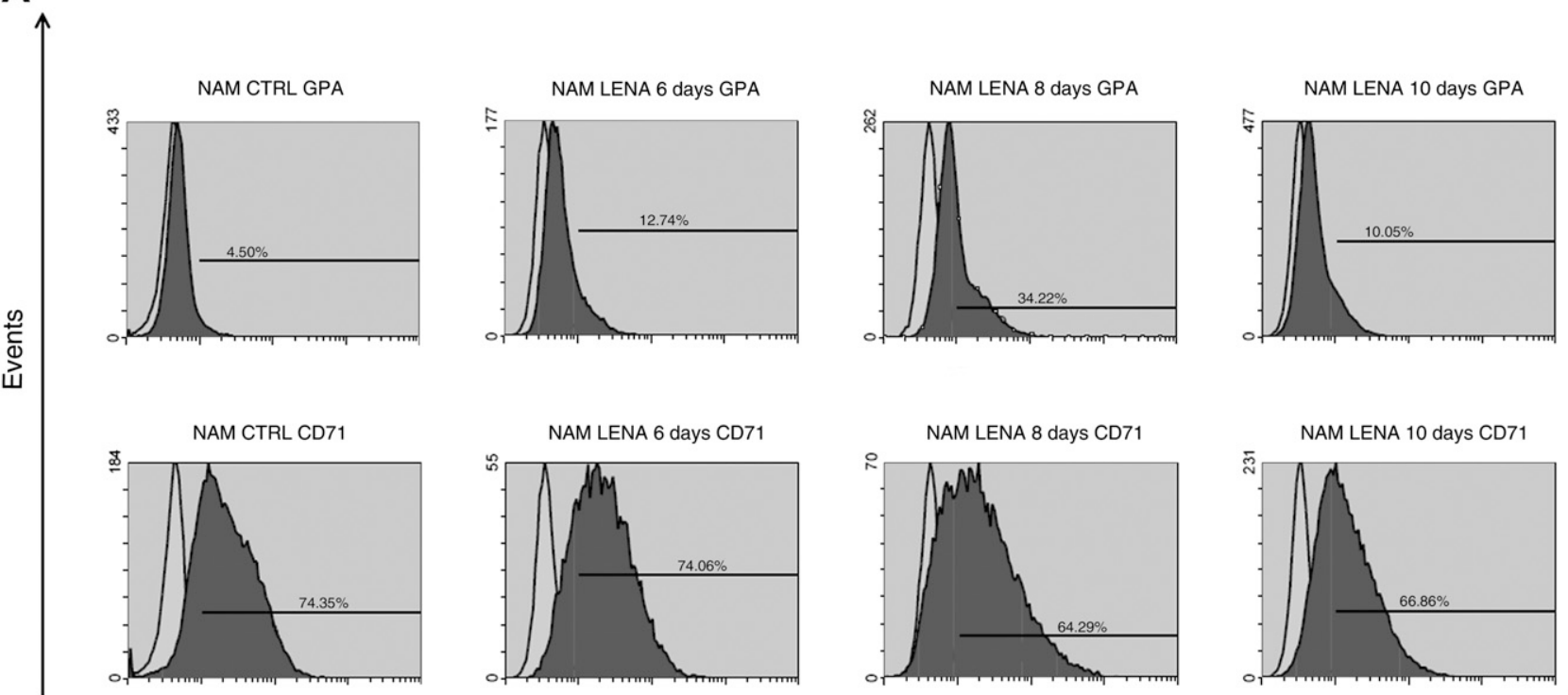

FITC

B
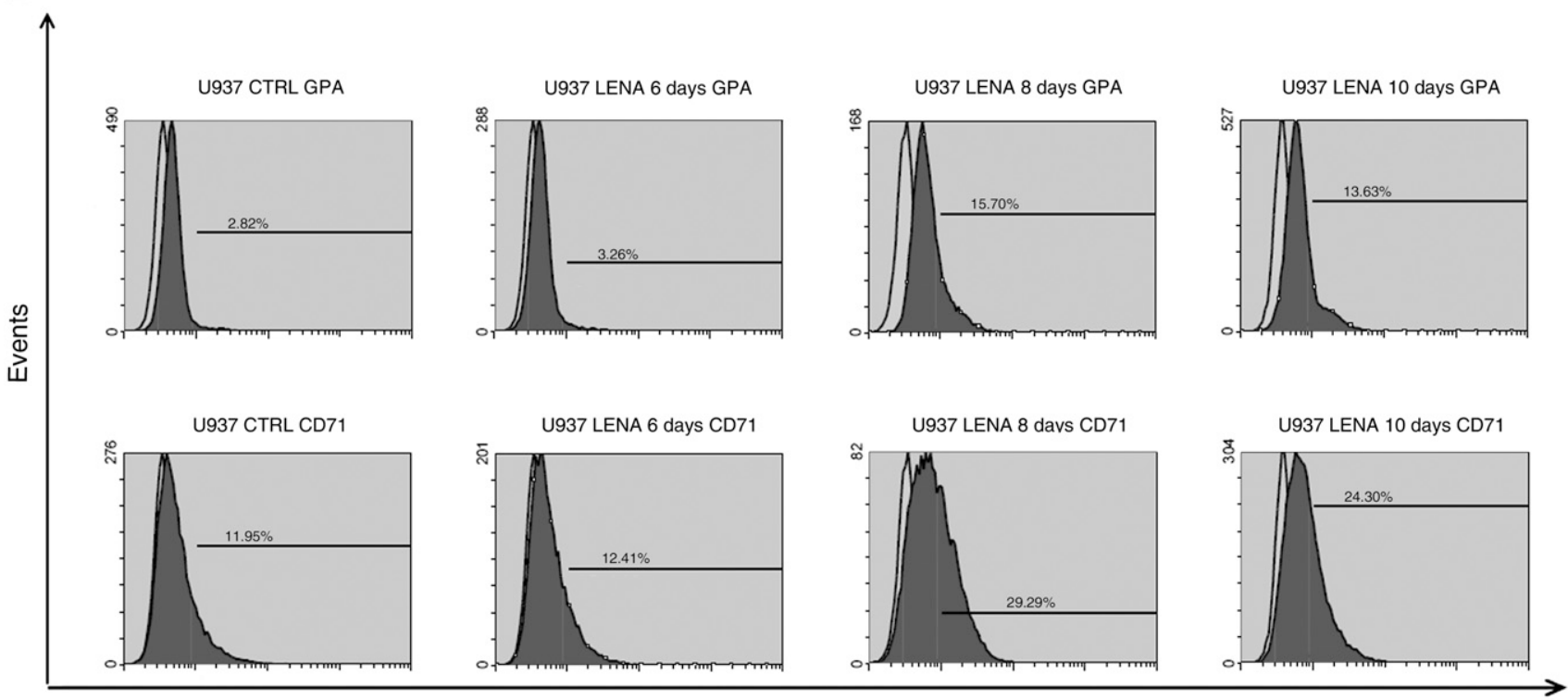

FITC

Figure 4. Lenalidomide increases the expression of erythroid-specific surface markers in del(5q) cells. A) Flow cytometric analysis of surface GPA and CD71 expression in Namalwa CSN.70 [NAM, i.e., del(5q) cells] treated with lenalidomide (Lena). As compared to control, on d 8 of treatment, GPA was significantly induced, whereas the percentage of CD $71^{+}$cells decreased. Data are representative of $\geq 3$ independent experiments. B) Flow cytometric analysis of surface GPA and CD71 expression in U937 cells [i.e., non-del $(5 q)$ cells] treated with lenalidomide (Lena). The expression of both GPA and CD71 surface markers increased during the treatment. Data are representative of $\geq 3$ independent experiments. 
untreated cells, lenalidomide induced a significant accumulation in the $\mathrm{G}_{0} / \mathrm{G}_{1}$ phase of Namalwa CSN.70 cells [i.e., del $(5 q)$ cells] after 6 and $8 \mathrm{~d}$ of treatment with lenalidomide (+16.6 and $19.3 \%$, respectively), before being reduced at $\mathrm{d} 10$ of the treatment. In particular, the final amount of $\mathrm{G}_{0} / \mathrm{G}_{1} \operatorname{del}(5 \mathrm{q})$ cells on $\mathrm{d} 6$ was $78.48 \%$, and on $\mathrm{d} 8$ that percentage increased to $80.98 \%$ (Fig. $3 A$ ). In contrast, U937 cells [i.e., non-del(5q) cells] showed a slight increase in $\mathrm{G}_{0} / \mathrm{G}_{1}$ phase only after $8 \mathrm{~d}$ of treatment $(+4.1 \%$ as compared with untreated cells), before being reduced on $\mathrm{d} 10$ of the treatment (Fig. 3A).

\section{Lenalidomide effect on cell cycle protein expression in del(5q) and non-del(5q) cell lines}

Because lenalidomide treatment could be associated with a change of cell cycle profiling (Fig. $3 A$ ), we also performed Western blot analyses on del(5q) and non-del(5q) cell lines, focusing on cell cycle protein expression (Fig. 3B). During lenalidomide treatment, Namalwa CSN.70 cells [i.e., del(5q) cells] displayed a significant increase of p21 and p27, a slight decrease of cyclin D3 and an almost constant low amount of cyclin E (Fig. 3B). In contrast, as compared with untreated cells, the expression of p21, p27, and cyclin D3 was maintained in U937 cells [i.e., non-del(5q) cells], whereas cyclin $E$ was induced in the last days of treatment with lenalidomide (Fig. 3B).

\section{Flow cytometric analysis of erythropoiesis activation in del(5q) and non-del(5q) cell lines}

The expression of both GPA and CD71 surface erythroidspecific proteins was quantified in $\operatorname{del}(5 q)$ and non-del $(5 q)$ cell lines during lenalidomide treatment by flow cytometry. As Fig. 4 shows, Namalwa CSN.70 cells [i.e., del(5q) cells] displayed a significant increase in GPA $(+29.72 \%)$, but not of CD71 (-10.06\%) after $8 \mathrm{~d}$ of treatment, as compared with untreated cells. Therefore, in those $\operatorname{del}(5 q)$ cells and after $8 \mathrm{~d}$ of lenalidomide treatment, the maximum level of GPA expression was $34.22 \%$, whereas CD71 expression showed a minor decrease. Conversely, the treatment with lenalidomide induced a significant increase in both GPA and CD71 in U937 cells [i.e., non$\operatorname{del}(5 \mathrm{q})$ cells] after $8 \mathrm{~d}$ of treatment $(+12.88$ and $17.34 \%$, respectively), which was even maintained on d 10 of treatment (Fig. 4).

\section{Lenalidomide effect on globin genes and PI-PLC $\beta 1$ expression in del(5q) and non-del(5q) cell lines}

As Fig. 5 shows, the effect of lenalidomide on the expression of globin genes and both PI-PLC $\beta 1$ splicing variants in $\operatorname{del}(5 q)$ and non-del $(5 q)$ hematopoietic cell lines was studied. Namalwa CSN.70 cells [i.e., del(5q) cells] showed a statistically significant decrease in the $\gamma / \beta$-globin ratio from d 6 of lenalidomide treatment, which was even higher on $\mathrm{d} 8$ and 10 (Student's $t$ test, $P<$ 0.05 vs. baseline, $95 \%$ CI -0.04 to -1.63$)$. They showed a minor, insignificant increase in PI-PLC $\beta 1$ a mRNA during lenalidomide treatment, as compared with untreated cells (Student's $t$ test, $P>0.05$ vs. baseline, $95 \% \mathrm{CI}-0.87$ to $+0.74)$, whereas the amount of PI-PLC $\beta 1 \mathrm{~b}$ mRNA showed an irrelevant decrease on $\mathrm{d} 8$ and 10 of lenalidomide (Student's $t$ test, $P>0.05$ vs. baseline, $95 \% \mathrm{CI}-0.02$ to +0.02$)$. As for U937 cells [i.e., non-del(5q) cells], they displayed an increased $\gamma / \beta$ globin ratio during lenalidomide therapy, although without a statistically significant difference before and after treatment (Student's $t$ test, $P>0.05$ vs. baseline,
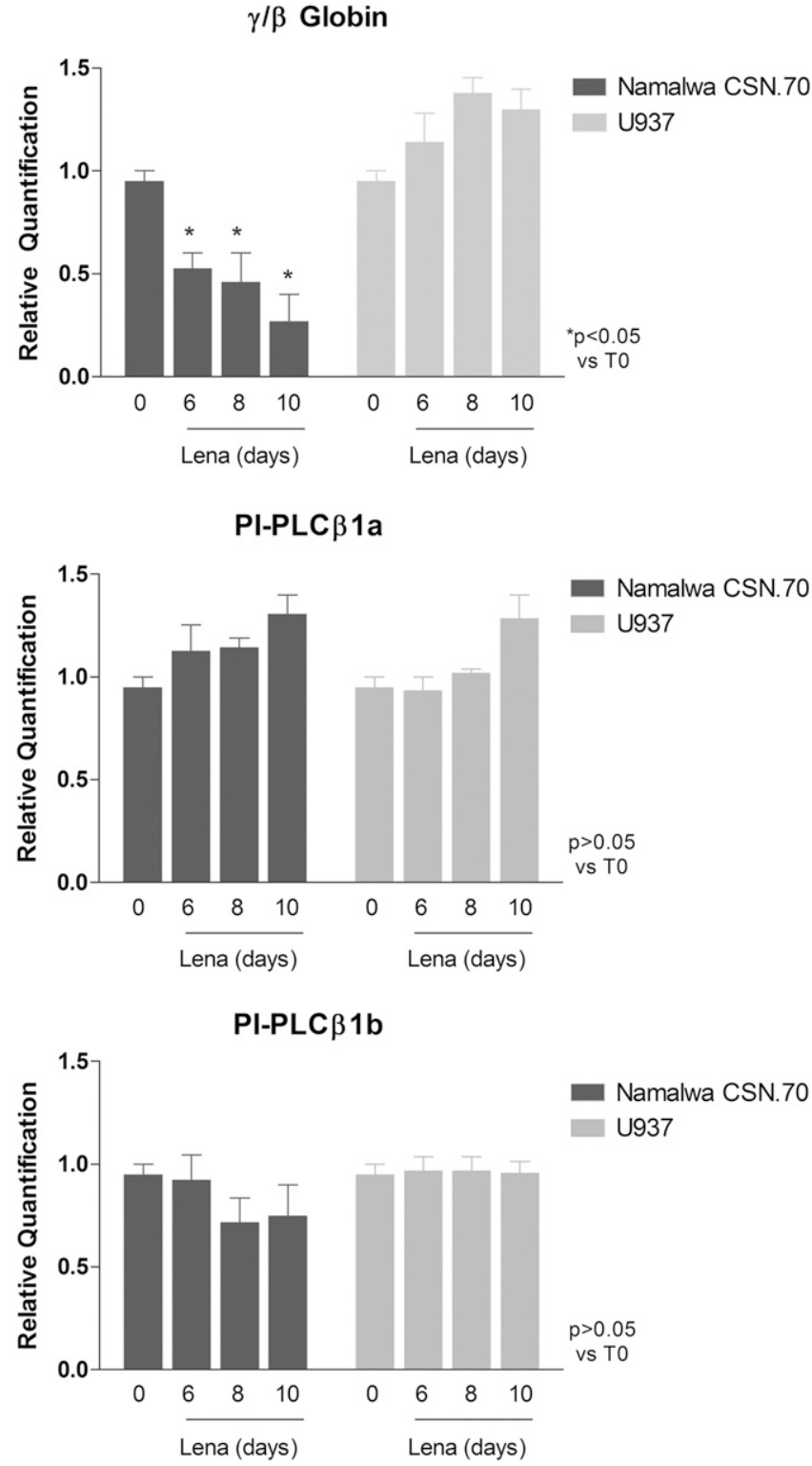

Figure 5. Lenalidomide reduces $\gamma / \beta$ globin ratio and induces PI-PLC $\beta 1$ a mRNA in $\operatorname{del}(5 q)$ cells. In Namalwa CSN.70 cells [i.e., $\operatorname{del}(5 q)$ cells], the $\gamma / \beta$-globin ratio significantly decreased during the therapy, whereas the expression of globin genes in U937 cells [i.e., non-del $(5 q)$ cells] was not significantly affected. In contrast, in both cell lines, the expression of the PI-PLCßla splicing variant was induced by lenalidomide (Lena) in the last days of treatment, although without statistical significance, whereas PI-PLC $\beta 1 b$ splicing variant was not significantly affected, especially in U937 cells. ${ }^{P} P<$ 0.05 vs. $T_{0}$. 
95\% CI 0.01-0.07). In addition, PI-PLC $\beta 1$ a mRNA increased slightly in those non-del(5q) cells during lenalidomide treatment, although that happened late and was not statistically significant (Student's $t$ test, $P>0.05$ vs. baseline, 95\% CI 0.01-0.05). In contrast, the amount of PI-PLCbeta1b mRNA was almost constant in these non-del(5q) cells. (Student's $t$ test, $P>0.05$ vs. baseline, $95 \%$ CI -0.01 to +0.02$)$.

\section{Lenalidomide effect on the expression of PI-PLC $\beta 1$ and PKC- $\alpha$ in del(5q) and non-del(5q) cell lines}

Given the results obtained by the gene expression analyses (Fig. 5), we also quantified the protein levels of PIPLC $\beta 1$ and its downstream target PKC- $\alpha$ by Western blot analyses on total lysates (Fig. 6). As compared with untreated cells, Namalwa CSN.70 cells [i.e., del(5q) cells] showed a very slight increase in PI-PLC $\beta 1$ in the last days of treatment with lenalidomide, whereas PKC- $\alpha$ was significantly reduced, primarily on d 8 and 10 of treatment. Conversely, U937 cells [i.e., non-del $(5 q)$ cells] displayed an almost constant amount of both PI-PLC $\beta 1$ and PKC- $\alpha$ during the entire lenalidomide treatment (Fig. 6).

\section{Lenalidomide effect on the expression of PI-PLC $\beta 1$ and PKC- $\alpha$ in nuclear and cytoplasmic fractions of $\operatorname{del}(5 q)$ and non-del(5q) cell lines}

Because the cellular localization of inositide-dependent molecules can be essential for their function and given that the PI-PLC $\beta 1$ antibody we used does not specifically discriminate between the 2 PI-PLC $\beta 1$ splicing variants, we also analyzed the subcellular localization of both PI-PLC $\beta 1$ and PKC- $\alpha$ in del(5q) and non-del(5q) cell lines during lenalidomide treatment (Fig. 7). As Fig. $7 A$ shows, during lenalidomide treatment, PIPLC $\beta 1$ was barely expressed in the nuclear fraction of
Namalwa CSN.70 cells [i.e., del(5q) cells], where, instead, PKC- $\alpha$ appeared to be detectable, especially after $8 \mathrm{~d}$ of treatment. Conversely, PI-PLC $\beta 1$ protein seemed to be localized mainly in the cytoplasmic fraction of the $\operatorname{del}(5 q)$ cells, with a peak expression after $10 \mathrm{~d}$ of lenalidomide treatment, whereas PKC alpha protein expression showed a small reduction. In contrast, in U937 cells [i.e., non-del $(5 q)$ cells] lenalidomide did not induce a cytoplasmic localization of PI-PLC $\beta 1$ nor a nuclear translocation of PKC- $\alpha$. Indeed, in these non-del(5q) cells, PI-PLC $\beta 1$ seemed to be mostly localized within the nucleus and PKC- $\alpha$ was detected mainly in the cytoplasmic fraction (Fig. $7 B$ ).

\section{DISCUSSION}

Nuclear inositide signaling pathways are deregulated in MDS, and nuclear PI-PLC $\beta 1$ is a negative regulator of erythroid differentiation. Moreover, nuclear PI-PLC $\beta 1$ specifically targets PKC- $\alpha$, which, in turn, has been associated with proliferation and differentiation of human erythroleukemia cells (42).

Lenalidomide is currently used in patients with MDS bearing a deletion of chromosome band $5 q$, who show a favorable outcome in most cases. The molecular mechanisms underlying this therapy in patients with del(5q) are still unclear, although lenalidomide improves their erythropoiesis, which is characteristically impaired, and possibly arrests their clonal cell proliferation.

In this study, we focused on the molecular erythroid effect of lenalidomide, analyzing the PI-PLC $\beta 1 /$ PKC- $\alpha$ signaling, which is linked to erythropoiesis, and testing the expression of GPA, CD71, or the globin genes (Tables 2 and 3). Indeed, the expression of globin genes is associated with either early or late erythropoiesis, because $\gamma$-globin is the first to be detected and $\beta$-globin is found in later stages, which is why a decreased value of the ratio between $\gamma$ and $\beta$-globin mRNAs suggests an
NAMALWA CSN.70 LENALIDOMIDE (days)

$\begin{array}{llll}\text { CTRL } & 6 & 8 & 10\end{array}$
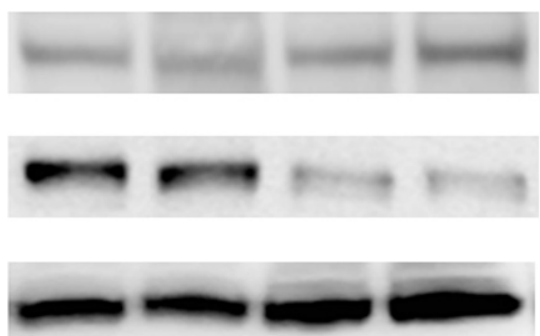

U937

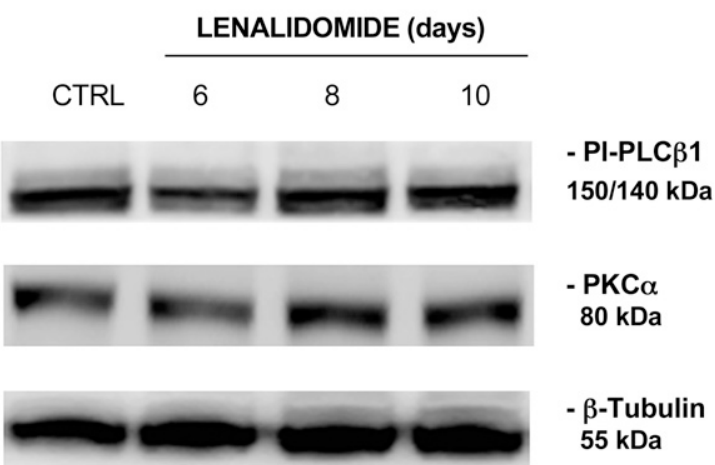

Figure 6. Lenalidomide induces PI-PLC $\beta 1$ and decreases PKC- $\alpha$ protein expression in del(5q) cells. Western blotting analyses of Namalwa CSN.70 [i.e., del(5q) cells] and U937 cell lines [i.e., non-del(5q) cells] treated with lenalidomide. The treatment slightly increased the levels of PI-PLCß1 in Namalwa CSN.70 cells, which also showed a decrease in PKC- $\alpha$. In contrast, the amount of PI-PLC $\beta 1$ and PKC- $\alpha$ was almost constant in the last days of treatment, in U937 cells. Antibody to $\beta$-tubulin served as a loading control. Molecular weights are indicated on the right. Data are representative of $\geq 3$ independent experiments. 

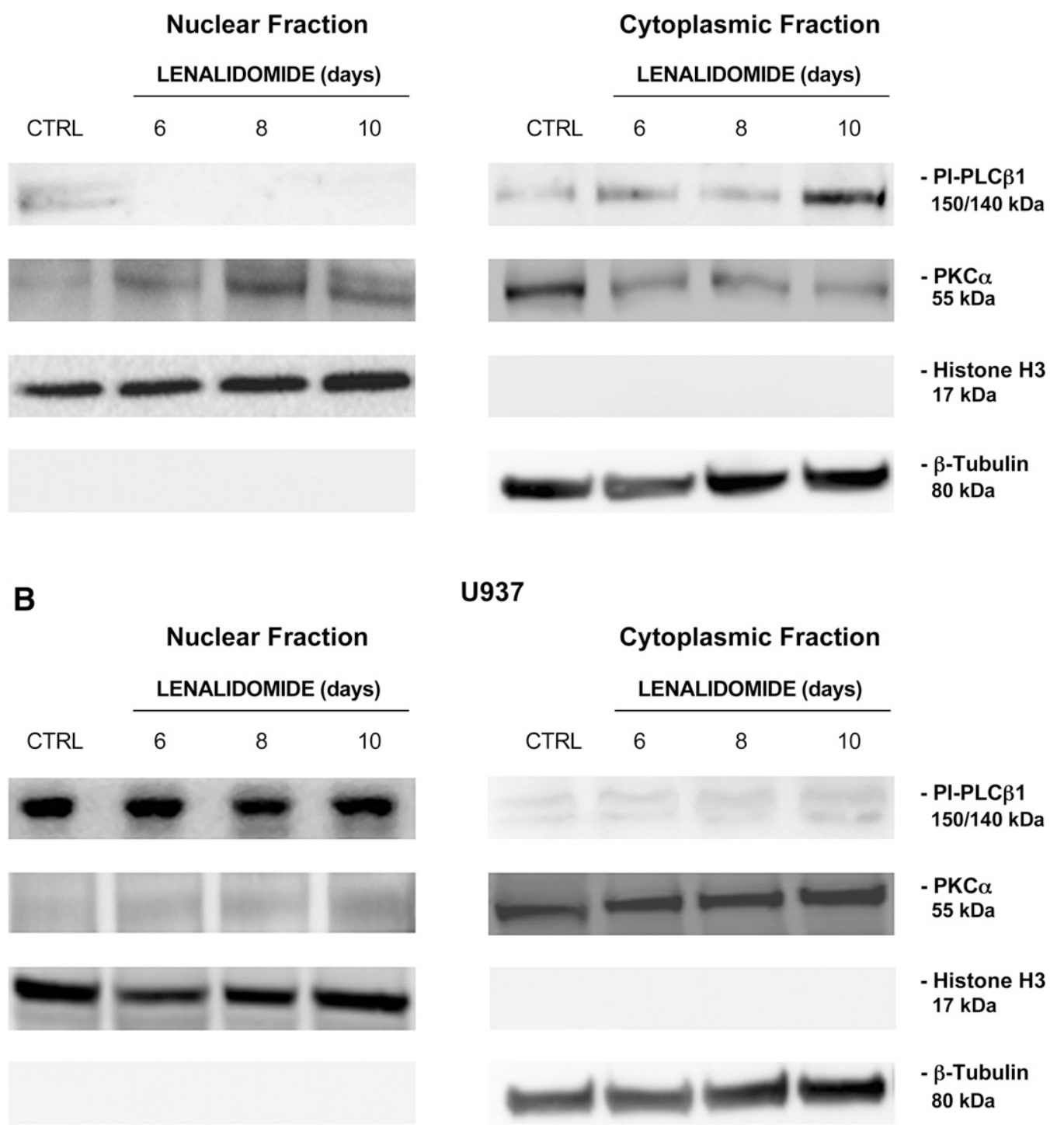

U937

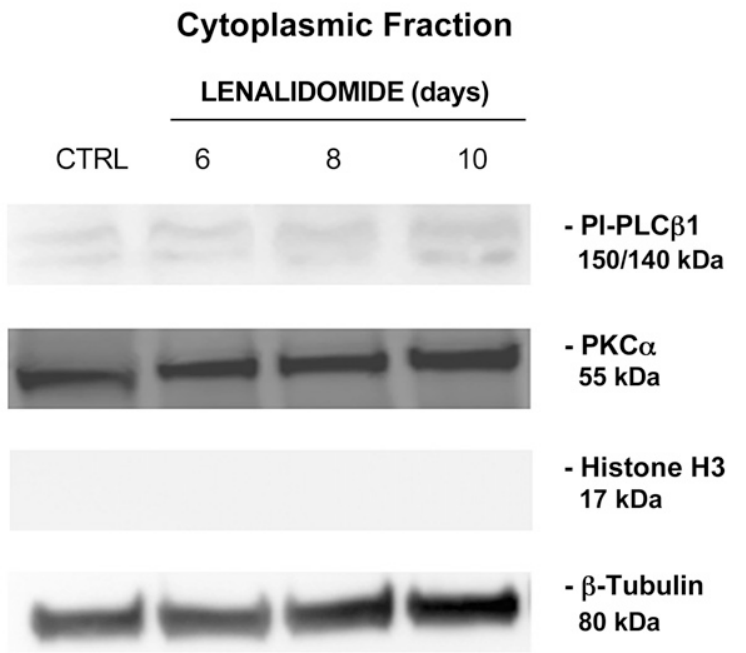

Figure 7. PKC- $\alpha$ is highly localized into the nucleus of $\operatorname{del}(5 \mathrm{q})$ cells after lenalidomide treatment. A) Nuclei and cytoplasms of Namalwa CSN.70 cells [i.e., $\operatorname{del}(5 \mathrm{q})$ cells] were separated before and after treatment with lenalidomide. Immunoblot assays during lenalidomide indicated PI-PLC $\beta 1$ as highly present in the cytoplasmic fraction, whereas PKC- $\alpha$ seemed to be mainly localized in the nuclear compartment. B) Nuclei and cytoplasms of U937 cells [i.e., non-del(5q) cells] were separated before and after treatment with lenalidomide. Immunoblot assays indicated that neither PI-PLC $\beta 1$ nor PKC- $\alpha$ were significantly affected by lenalidomide treatment, with a prevalent nuclear localization for PI-PLC $\beta 1$ and a cytoplasmic localization for PKC- $\alpha$. For all experiments, antibody to $\beta$-tubulin served as a loading control and a control for cytoplasm purity, whereas H3A antibody served as a loading control and a control for nuclear purity. Molecular weights are indicated on the right. Data are representative of $\geq 3$ independent experiments.

induction of erythroid differentiation, and an activation of erythropoiesis.

To begin with, we investigated the effect of lenalidomide in MNCs obtained from del(5q) low-risk patients with MDS. In our case series, 5 of 16 patients discontinued lenalidomide treatment early, and for those patients, neither a clinical assessment of lenalidomide effect nor a molecular analysis were possible. Among the remaining patients, 10 subjects responded to lenalidomide, whereas the nonresponding patient showed a stable disease after treatment. At a molecular level, only responders showed an activation of erythropoiesis, in that the $\gamma / \beta$-globin ratio decreased, as compared with baseline. Moreover, those subjects displayed a specific increase of PI-PLC $\beta 1$ a, but not PI-PLC $\beta 1 b$, mRNA, especially in the last cycles of therapy. The protein expression of PI-PLC $\beta 1$, as well as its downstream target PKC- $\alpha$, were also investigated. In particular, we performed double immunostaining with PP2CA and PI-PLC $\beta 1$ or PKC- $\alpha$ on MDS MNCs. Because the PP2CA gene is localized in the $5 \mathrm{q}$ chromosome band, cells showing both proteins were considered non$\operatorname{del}(5 q)$ cells, whereas cells with a low amount of $P P 2 C A$ were del(5q) cells. Surprisingly, we detected a distinct 
TABLE 2. Outline of the results obtained: effects of lenalidomide on erythropoiesis

\begin{tabular}{|c|c|c|c|}
\hline Test & MDS cells from responders & Namalwa CSN.70 del $(5 q)$ cells & U937 non-del(5q) cells \\
\hline $\begin{array}{l}\gamma / \beta \text { globin } \\
\text { ratio }\end{array}$ & Significantly decreased (Fig. 1) & Significantly decreased (Fig. 5) & $\begin{array}{l}\text { Slightly increased in the late cycles } \\
\text { (Fig. 5) }\end{array}$ \\
\hline $\begin{array}{l}\text { PI-PLCß1a } \\
\text { mRNA }\end{array}$ & Increased in the late cycles (Fig. 1) & $\begin{array}{l}\text { Minor increase in the last days } \\
\text { of treatment (Fig. } 5 \text { ) }\end{array}$ & $\begin{array}{l}\text { Almost constant/slightly increased in } \\
\text { the last days of treatment (Fig. 5) }\end{array}$ \\
\hline $\begin{array}{l}\text { PI-PLCß1b } \\
\text { mRNA }\end{array}$ & Almost constant (Fig. 1) & $\begin{array}{l}\text { Slightly decreased in the last } \\
\text { days of treatment (Fig. 5) }\end{array}$ & Almost constant (Fig. 5) \\
\hline $\begin{array}{l}\text { PI-PLC } \beta 1 \\
\text { protein }\end{array}$ & $\begin{array}{l}\text { Cytoplasmic localization in del }(5 q) \\
\text { cells (Fig. } 2) \text {; nuclear localization } \\
\text { in non-del(5q) cells (Fig. } 2)\end{array}$ & $\begin{array}{l}\text { Slightly increased in total } \\
\text { lysates (Fig. 6); cytoplasmic } \\
\text { localization (Fig. 7) }\end{array}$ & $\begin{array}{l}\text { Almost constant in total lysates (Fig. } \\
\text { 6); nuclear localization (Fig. 7) }\end{array}$ \\
\hline PKC- $\alpha$ & $\begin{array}{l}\text { Nuclear translocation in del }(5 q) \text { cells } \\
\text { (Fig. } 2) \text {; cytoplasmic localization in } \\
\text { non-del }(5 q) \text { cells (Fig. } 2)\end{array}$ & $\begin{array}{l}\text { Decreased in total lysates (Fig. } \\
\text { 6); nuclear translocation } \\
\text { (Fig. 7) }\end{array}$ & $\begin{array}{l}\text { Almost constant in total lysates (Fig. } \\
6 \text { ); cytoplasmic localization (Fig. } 7 \text { ) }\end{array}$ \\
\hline
\end{tabular}

behavior between $\operatorname{del}(5 q)$ and non-del(5q) MDS cells from responder patients in that, during lenalidomide therapy, PI-PLC $\beta 1$ seemed to be localized mainly in the cytoplasm of the del $(5 q)$ cells, whereas, in the same subpopulation, PKC- $\alpha$ translocated to the nucleus.

To better discriminate between $\operatorname{del}(5 q)$ and non-del (5q) cells, we studied the effect of lenalidomide on hematopoietic cell lines, using Namalwa CSN.70 cells, showing a del(5q) karyotype, and U937 cells, showing a healthy $5 \mathrm{q}$ chromosome band. As for the erythroid effect, Namalwa CSN.70 cells showed a decrease in the $\gamma / \beta$-globin ratio, an increase in GPA, and a reduction in CD71 erythroid-specific surface markers during lenalidomide treatment, confirming the induction of erythropoiesis in those del(5q) cells. In contrast, U937 cells treated with lenalidomide showed a higher amount of not only globin genes but also both GPA and CD71 markers. This indicated that, in these non-del(5q) cells, the erythroid differentiation was not specifically induced, although the almost constant amount of PIPLC $\beta 1 \mathrm{~b}$ during lenalidomide treatment in those non$\operatorname{del}(5 q)$ cells also showed that the erythropoiesis was not specifically inhibited. In fact, the PI-PLC $\beta 1$ a splicing variant was generally localized primarily in the cytoplasm, where it is not directly associated with inhibition of erythroid differentiation, whereas nuclear PI-PLC $\beta 1$ (i.e., the PI-PLC $\beta 1 \mathrm{~b}$ splicing variant) is a known negative regulator of erythropoiesis. Our data on cell lines showed that lenalidomide specifically induced the expression of PI-PLC $\beta 1$ in the cytoplasm of
Namalwa CSN.70 [i.e., del(5q) cells], where a nuclear translocation of PKC- $\alpha$, which can be associated with erythropoiesis, was also detected.

Our study also tried to determine the molecular mechanisms underlying the specific clonal cell arrest induced by lenalidomide because, in most patients with MDS who respond, the therapy can reduce the proliferation of the del(5q) clone. To that end, we tested the effect of lenalidomide on $\operatorname{del}(5 q)$ and non-del $(5 q)$ hematopoietic cell lines (Table 3). Only Namalwa CSN.70 cells [i.e., del(5q) cells] showed a lenalidomide-dependent arrest of the cell cycle in the $G_{0} / G_{1}$ phase, which also corresponded to an increase in p21 and p27 and a slightly decreased expression of cyclin D3 and cyclin E. In contrast, in non-del(5q) cells (i.e., U937 cells), lenalidomide did not significantly affect the cell cycle. Therefore, our data show that lenalidomide can induce a selective arrest of the cell cycle in $G_{0} / G_{1}$ phase of $\operatorname{del}(5 q)$ cells, thus slowing the rate proliferation of that cell clone. In contrast, p21, p27, cyclins, globin genes, CD71, and GPA are specifically activated in non-del $(5 q)$ cells, possibly leading to cell proliferation and erythroid differentiation within reference ranges. Therefore, lenalidomide seems specifically to slow the proliferation of the $\operatorname{del}(5 q)$ clone, promoting, instead, its erythroid differentiation.

In summary, our findings may be important not only to further understand the role of inositide-dependent signaling in erythropoiesis but also to better comprehend the lenalidomide effect on del( $5 q)$ MDS and pave the way toward innovative, targeted therapies.

TABLE 3. Outline of the results obtained by a flow cytometric approach: effects of lenalidomide on cell cycle and erythroid-surface markers

\begin{tabular}{|c|c|c|}
\hline Test & Namalwa CSN.70 $\operatorname{del}(5 q)$ cells & U937 non-del(5q) cells \\
\hline Cell cycle & $\begin{array}{l}\text { Significant accumulation in the } \\
\mathrm{G}_{0} / \mathrm{G}_{1} \text { phase (Fig. 3) }\end{array}$ & $\begin{array}{l}\text { Slightly, insignificant increase in } \\
\mathrm{G}_{0} / \mathrm{G}_{1} \text { phase (Fig. 3) }\end{array}$ \\
\hline Cell cycle protein expression & $\begin{array}{l}\text { Significant increase of p21 and p27, } \\
\text { a slight decrease of cyclin D3, and } \\
\text { an almost constant low amount of } \\
\text { cyclin E (Fig. 3) }\end{array}$ & $\begin{array}{l}\text { Almost constant expression of p21, } \\
\text { p27, and cyclin D3, slight } \\
\text { insignificant late induction of } \\
\text { cyclin E (Fig. 3) }\end{array}$ \\
\hline $\begin{array}{l}\text { GPA and CD71 flow cytometric } \\
\text { expression }\end{array}$ & $\begin{array}{l}\text { Significant increase of GPA } \\
\quad(+29.72 \%), \text { but not of CD71 } \\
(-10.06 \%) \text { after } 8 \mathrm{~d} \text { of treatment } \\
\text { (Fig. } 4)\end{array}$ & $\begin{array}{l}\text { Significant increase of both GPA } \\
(+12.88 \%) \text { and CD71 }(+17.34 \%) \\
\text { after } 8 \mathrm{~d} \text { of treatment (Fig. } 4)\end{array}$ \\
\hline
\end{tabular}




\section{ACKNOWLEDGMENTS}

This work was supported by grants from the Italian Ministero dell'Istruzione dell'Università e della RicercaProgetti di Ricerca di Interesse Nazionale and Intesa S. Paolo. The authors declare no conflicts of interest.

\section{AUTHOR CONTRIBUTIONS}

A. Poli, S. Ratti, S. Mongiorgi, A. Lonetti, A. Cappellini, A. Catozzi, and M. Y. Follo performed the research; C. Finelli, L. Manzoli, L. Cocco, and M. Y. Follo designed the research study; C. Clissa, M. Barraco, P.-G. Suh, and J.A. McCubrey contributed essential reagents or tools and provided clinical samples and data; A. Poli, S. Ratti, C. Finelli, S. Mongiorgi, L. Cocco, and M. Y. Follo analyzed the data; A. Poli, C. Finelli, L. Cocco, and M. Y. Follo wrote the paper; and all authors revised it critically and approved the final version.

\section{REFERENCES}

1. Stahl, M., and Zeidan, A. M. (2017) Lenalidomide use in myelodysplastic syndromes: insights into the biologic mechanisms and clinical applications. Cancer 123, 1703-1713

2. Basiorka, A. A., McGraw, K. L., De Ceuninck, L., Griner, L. N., Zhang, L., Clark, J. A., Caceres, G., Sokol, L., Komrokji, R. S., Reuther, G. W., Wei, S., Tavernier, J., and List, A. F. (2016) Lenalidomide stabilizes the erythropoietin receptor by inhibiting the E3 ubiquitin ligase RNF41. Cancer Res. 76, 3531-3540

3. Narla, A., Dutt, S., McAuley, J. R., Al-Shahrour, F., Hurst, S., McConkey, M., Neuberg, D., and Ebert, B. L. (2011) Dexamethasone and lenalidomide have distinct functional effects on erythropoiesis. Blood 118, 2296-2304

4. Gandhi, A. K., Kang, J., Naziruddin, S., Parton, A., Schafer, P. H., and Stirling, D. I. (2006) Lenalidomide inhibits proliferation of Namalwa CSN.70 cells and interferes with Gab1 phosphorylation and adaptor protein complex assembly. Leuk. Res. 30, 849-858

5. Mongiorgi, S., Finelli, C., Yang, Y. R., Clissa, C., McCubrey, J. A., Billi, A. M., Manzoli, L., Suh, P. G., Cocco, L., and Follo, M. Y. (2016) Inositide-dependent signaling pathways as new therapeutic targets in myelodysplastic syndromes. Expert Opin. Ther. Targets 20, 677-687

6. Mongiorgi, S., Follo, M.Y., Yang,Y. R., Ratti, S., Manzoli, L., McCubrey, J. A., Billi, A. M., Suh, P. G., and Cocco, L. (2016) Selective activation of nuclear PI-PLC $\beta 1$ during normal and therapy-related differentiation. Curr. Pharm. Des. 22, 2345-2348

7. Follo, M. Y., Mongiorgi, S., Clissa, C., Paolini, S., Martinelli, G., Martelli, A. M., Fioravanti, G., Manzoli, L., Finelli, C., and Cocco, L. (2012) Activation of nuclear inositide signalling pathways during erythropoietin therapy in low-risk MDS patients. Leukemia 26, 2474-2482

8. Myklebust, J. H., Blomhoff, H. K., Rusten, L. S., Stokke, T., and Smeland, E. B. (2002) Activation of phosphatidylinositol 3-kinase is important for erythropoietin-induced erythropoiesis from $\mathrm{CD} 34\left(^{+}\right)$ hematopoietic progenitor cells. Exp. Hematol. 30, 990-1000

9. Poli, A., Mongiorgi, S., Cocco, L., and Follo, M. Y. (2014) Protein kinase C involvement in cell cycle modulation. Biochem. Soc. Trans. 42, 1471-1476

10. Follo, M. Y., Faenza, I., Piazzi, M., Blalock, W. L., Manzoli, L., McCubrey, J. A., and Cocco, L. (2014) Nuclear PI-PLCß1: an appraisal on targets and pathology. Adv. Biol. Regul. 54, 2-11

11. Follo, M. Y., Marmiroli, S., Faenza, I., Fiume, R., Ramazzotti, G., Martelli, A. M., Gobbi, P., McCubrey, J. A., Finelli, C., Manzoli, F. A., and Cocco, L. (2013) Nuclear phospholipase C $\beta 1$ signaling, epigenetics and treatments in MDS. Adv. Biol. Regul. 53, 2-7

12. Mongiorgi, S., Follo, M. Y., Clissa, C., Giardino, R., Fini, M., Manzoli, L., Ramazzotti, G., Fiume, R., Finelli, C., and Cocco, L. (2012) Nuclear PI-PLC $\beta 1$ and myelodysplastic syndromes: from bench to clinics. Curr. Top. Microbiol. Immunol. 362, 235-245

13. Faenza, I., Billi, A. M., Follo, M.Y., Fiume, R., Martelli, A. M., Cocco, L., and Manzoli, L. (2005) Nuclear phospholipase C signaling through type 1 IGF receptor and its involvement in cell growth and differentiation. Anticancer Res. 25, 2039-2041

14. Martelli, A. M., Fiume, R., Faenza, I., Tabellini, G., Evangelista, C., Bortul, R., Follo, M. Y., Falà, F., and Cocco, L. (2005) Nuclear phosphoinositide specific phospholipase C (PI-PLC) $-\beta$ 1: a central intermediary in nuclear lipid-dependent signal transduction. Histol. Histopathol. 20, 1251-1260

15. Poli, A., Fiume, R., Baldanzi, G., Capello, D., Ratti, S., Gesi, M., Manzoli, L., Graziani, A., Suh, P. G., Cocco, L., and Follo, M. Y. (2017) Nuclear localization of diacylglycerol kinase alpha in K562 cells is involved in cell cycle progression. J. Cell. Physiol. 232, 2550-2557

16. Ramazzotti, G., Faenza, I., Fiume, R., Billi, A. M., Manzoli, L., Mongiorgi, S., Ratti, S., McCubrey, J. A., Suh, P. G., Cocco, L., and Follo, M. Y. (2017) PLC- $\beta 1$ and cell differentiation: an insight into myogenesis and osteogenesis. Adv. Biol. Regul. 63, 1-5

17. Cocco, L., Manzoli, L., Faenza, I., Ramazzotti, G., Yang, Y. R., McCubrey, J. A., Suh, P. G., and Follo, M. Y. (2016) Modulation of nuclear PI-PLCß1 during cell differentiation. Adv. Biol. Regul. 60, 1-5

18. Cocco, L., Follo, M. Y., Faenza, I., Billi, A. M., Ramazzotti, G., Martelli, A. M., Manzoli, L., and Weber, G. (2010) Inositide signaling in the nucleus: from physiology to pathology. Adv. Enzyme Regul. 50, 2-11

19. Bae, Y. S., Lee, H. Y., Jung, Y. S., Lee, M., and Suh, P. G. (2017) Phospholipase $\mathrm{C} \gamma$ in toll-like receptor-mediated inflammation and innate immunity. Adv. Biol. Regul. 63, 92-97

20. Cocco, L., Follo, M. Y., Manzoli, L., and Suh, P. G. (2015) Phosphoinositide-specific phospholipase $\mathrm{C}$ in health and disease. J. Lipid Res. 56, 1853-1860

21. Follo, M.Y., Manzoli, L., Poli, A., McCubrey, J.A., and Cocco, L. (2015) $\mathrm{PLC}$ and PI3K/Akt/mTOR signalling in disease and cancer. Adv. Biol. Regul. 57, 10-16

22. Follo, M.Y., Mongiorgi, S., Finelli, C., Clissa, C., Ramazzotti, G., Fiume, R., Faenza, I., Manzoli, L., Martelli, A. M., and Cocco, L. (2010) Nuclear inositide signaling in myelodysplastic syndromes. J. Cell. Biochem. 109, 1065-1071

23. Follo, M. Y., Faenza, I., Fiume, R., Ramazzotti, G., McCubrey, J. A. Martelli, A. M., Manzoli, F. A., and Cocco, L. (2012) Revisiting nuclear phospholipase C signalling in MDS. Adv. Biol. Regul. 52, 2-6

24. Follo, M.Y., Mongiorgi, S., Finelli, C., Piazzi, M., Faenza, I., Ramazzotti, G., Santi, P., McCubrey, J. A., Martelli, A. M., and Cocco, L. (2012) Nuclear PI-PLC 11 and myelodysplastic syndromes: genetics and epigenetics. Curr. Pharm. Des. 18, 1751-1754

25. Follo, M. Y., Russo, D., Finelli, C., Mongiorgi, S., Clissa, C., Filì, C., Colombi, C., Gobbi, M., Manzoli, L., Piazzi, M., Martelli, A. M., and Cocco, L. (2012) Epigenetic regulation of nuclear PI-PLCbetal signaling pathway in low-risk MDS patients during azacitidine treatment. Leukemia 26, 943-950

26. Cocco, L., Finelli, C., Mongiorgi, S., Clissa, C., Russo, D., Bosi, C., Quaranta, M., Malagola, M., Parisi, S., Stanzani, M., Ramazzotti, G., Mariani, G. A., Billi, A. M., Manzoli, L., and Follo, M. Y. (2015) An increased expression of PI-PLC $\beta 1$ is associated with myeloid differentiation and a longer response to azacitidine in myelodysplastic syndromes. J. Leukoc. Biol. 98, 769-780

27. Manzoli, L., Mongiorgi, S., Clissa, C., Finelli, C., Billi, A. M., Poli, A., Quaranta, M., Cocco, L., and Follo, M. Y. (2014) Strategic role of nuclear inositide signalling in myelodysplastic syndromes therapy. Mini Rev. Med. Chem. 14, 873-883

28. Poli, A., Faenza, I., Chiarini, F., Matteucci, A., McCubrey, J. A., and Cocco, L. (2013) K562 cell proliferation is modulated by PLC $\beta 1$ through a PKC $\alpha$-mediated pathway. Cell Cycle 12, 1713-1721

29. Ratti, S., Mongiorgi, S., Ramazzotti, G., Follo, M. Y., Mariani, G. A., Suh, P. G., McCubrey, J. A., Cocco, L., and Manzoli, L. (2017) Nuclear inositide signaling via phospholipase C. J. Cell. Biochem. 118, 1969-1978

30. Poli, A., Billi, A. M., Mongiorgi, S., Ratti, S., McCubrey,J. A., Suh, P. G., Cocco, L., and Ramazzotti, G. (2016) Nuclear phosphatidylinositol signaling: focus on phosphatidylinositol phosphate kinases and phospholipases C. J. Cell. Physiol. 231, 1645-1655

31. Ramazzotti, G., Faenza, I., Fiume, R., Matteucci, A., Piazzi, M., Follo, M.Y., and Cocco, L. (2011) The physiology and pathology of inositide signaling in the nucleus. J. Cell. Physiol. 226, 14-20

32. Ramazzotti, G., Faenza, I., Follo, M. Y., Fiume, R., Piazzi, M., Giardino, R., Fini, M., and Cocco, L. (2011) Nuclear phospholipase C in biological control and cancer. Crit. Rev. Eukaryot. Gene Expr. 21, 291-301

33. Vardiman, J. W., Thiele, J., Arber, D. A., Brunning, R. D., Borowitz, M. J., Porwit, A., Harris, N. L., Le Beau, M. M., Hellström-Lindberg, E., Tefferi, A., and Bloomfield, C. D. (2009) The 2008 revision of the 
World Health Organization (WHO) classification of myeloid neoplasms and acute leukemia: rationale and important changes. Blood 114, 937-951

34. Greenberg, P. L., Tuechler, H., Schanz, J., Sanz, G., Garcia-Manero, G., Solé, F., Bennett, J. M., Bowen, D., Fenaux, P., Dreyfus, F., Kantarjian, H., Kuendgen, A., Levis, A., Malcovati, L., Cazzola, M., Cermak, J., Fonatsch, C., Le Beau, M. M., Slovak, M. L., Krieger, O., Luebbert, M., Maciejewski, J., Magalhaes, S. M., Miyazaki, Y., Pfeilstöcker, M., Sekeres, M., Sperr, W. R., Stauder, R., Tauro, S., Valent, P., Vallespi, T., van de Loosdrecht, A. A., Germing, U., and Haase, D. (2012) Revised international prognostic scoring system for myelodysplastic syndromes. Blood 120, 2454-2465

35. Cheson, B. D., Greenberg, P. L., Bennett, J. M., Lowenberg, B., Wijermans, P. W., Nimer, S. D., Pinto, A., Beran, M., de Witte, T. M., Stone, R. M., Mittelman, M., Sanz, G. F., Gore, S. D., Schiffer, C. A., and Kantarjian, H. (2006) Clinical application and proposal for modification of the International Working Group (IWG) response criteria in myelodysplasia. Blood 108, 419-425

36. Buontempo, F., Chiarini, F., Bressanin, D., Tabellini, G., Melchionda, F., Pession, A., Fini, M., Neri, L. M., McCubrey, J. A., and Martelli, A. M. (2012) Activity of the selective IкB kinase inhibitor BMS-345541 against T-cell acute lymphoblastic leukemia: involvement of FOXO3a. Cell Cycle 11, 2467-2475

37. Lonetti, A., Antunes, I. L., Chiarini, F., Orsini, E., Buontempo, F., Ricci, F., Tazzari, P. L., Pagliaro, P., Melchionda, F., Pession, A., Bertaina, A., Locatelli, F., McCubrey, J. A., Barata, J. T., and Martelli, A. M. (2014) Activity of the pan-class I phosphoinositide 3-kinase inhibitor NVP-BKM120 in T-cell acute lymphoblastic leukemia. Leukemia 28, 1196-1206

38. Follo, M. Y., Finelli, C., Mongiorgi, S., Clissa, C., Chiarini, F., Ramazzotti, G., Paolini, S., Martinelli, G., Martelli, A. M., and Cocco, L. (2011) Synergistic induction of PI-PLCß1 signaling by azacitidine and valproic acid in high-risk myelodysplastic syndromes. Leukemia 25, 271-280

39. Follo, M. Y., Finelli, C., Mongiorgi, S., Clissa, C., Bosi, C., Testoni, N., Chiarini, F., Ramazzotti, G., Baccarani, M., Martelli, A. M., Manzoli, L., Martinelli, G., and Cocco, L. (2009) Reduction of phosphoinositidephospholipase $\mathrm{C} \beta 1$ methylation predicts the responsiveness to azacitidine in high-risk MDS. Proc. Natl. Acad. Sci. USA 106, 16811-16816

40. Blalock, W. L., Bavelloni, A., Piazzi, M., Tagliavini, F., Faenza, I., Martelli, A. M., Follo, M. Y., and Cocco, L. (2011) Multiple forms of PKR present in the nuclei of acute leukemia cells represent an active kinase that is responsive to stress. Leukemia 25, 236-245

41. Poli, A., Ramazzotti, G., Matteucci, A., Manzoli, L., Lonetti, A., Suh, P. G., McCubrey, J. A., and Cocco, L. (2014) A novel DAG-dependent mechanism links PKCa and cyclin B1 regulating cell cycle progression. Oncotarget 5, 11526-11540

42. Bavelloni, A., Poli, A., Fiume, R., Blalock, W., Matteucci, A., Ramazzotti, G., McCubrey, J. A., Cocco, L., and Faenza, I. (2014) PLC- $\beta 1$ regulates the expression of miR-210 during mithramycinmediated erythroid differentiation in K562 cells. Oncotarget 5, 4222-4231

Received for publication July 24, 2017. Accepted for publication September 11, 2017. 